\title{
Lhermitte-Duclos Disease: Literature Review and Novel Treatment Strategy
}

\author{
Sagun Tuli, John P. Provias and Mark Bernstein
}

\begin{abstract}
Background: Lhermitte-Duclos disease (LDD) is a rare pathologic entity involving the cerebellum. The fundamental nature of the entity and its pathogenesis remain unknown, and considerable debate has centered on whether it represents a neoplastic, malformative or hamartomatous lesion. The cell or cells of origin remain incompletely defined. Previous reports of cases in the English literature have dealt predominantly with the clinical and pathological aspects yet few address issues of treatment. Methods: A case of Lhermitte-Duclos disease (LDD) in a 54-year-old female leading to local compressive symptoms and obstructive hydrocephalus is presented. A craniectomy, in addition to a $\mathrm{C} 1$ laminectomy followed by a decompressive duroplasty (using autologous fascia lata graft) was performed. Results: The patient clinically improved and follow-up MRI 11 months post-operatively revealed improvement in hydrocephalus. Conclusion: The histological and immunohistochemical features of the lesion are described, emphasizing the role of an abnormal dysplastic granule cell layer. The evidence in favor of each of the major theories of pathogenesis, malformative and neoplastic is discussed. Based on these facts a form of surgical intervention involving decompressive duroplasty is proposed.
\end{abstract}

RÉSUMÉ: Maladie de Lhermitte-Duclos: revue de la littérature et nouveau traitement. Introduction: La maladie de Lhermitte-Duclos est une pathologie rare impliquant le cervelet. La nature de la maladie et sa pathogenèse demeurent inconnues. On s'interroge toujours à savoir si la lésion est une néoplasie, une malformation ou un hamartome. La ou les cellules d'origine demeurent mal définies. Jusqu'à maintenant dans la littérature anglaise on s'est intéressé surtout aux aspects cliniques et anatomopathologiques et peu aux aspects thérapeutiques. Méthodes: Nous présentons un cas de maladie de Lhermitte-Duclos (MLD) qui a entraîné des symptômes de compression locale et d'hydrocéphalie obstructive chez une femme de 54 ans. Nous avons procédé à une crâniectomie et à une laminectomie au niveau de $\mathrm{C} 1$ suivies d'une duroplastie de décompression (au moyen d'une greffe autologue du fascia lata). Résultats: La patiente s'est améliorée cliniquement et la résonance magnétique effectuée 11 mois après l'intervention a montré une amélioration de l'hydrocéphalie. Conclusions: Nous décrivons les caractéristiques histologiques et immunohistochimiques de la lésion tout en insistant sur le rôle d'une couche anormale de cellules microgliales dysplasiques. Nous discutons des observations qui sont en faveur de chacune des théories sur la pathogenèse. En nous basant sur ces faits, nous proposons une forme unique d'intervention chirurgicale impliquant une duroplastie de décompression.

Can. J. Neurol. Sci. 1997; 24: 155-160

Lhermitte-Duclos disease (LDD) is a pathologic entity involving the cerebellum. The fundamental nature of the entity and its pathogenesis remain unknown, and considerable debate has centered on whether it represents a neoplastic, malformative or hamartomatous lesion. The cell or cells of origin remain incompletely defined although it is generally felt that an abnormality of the granule cells plays a prominent role. Whether Purkinje cells and/or other normal cellular elements of the cerebellar cortex are involved remains to be defined. Reflecting this confusion and limited understanding, numerous descriptive names have appeared in the literature including cerebellar hamartoma, neurocytic blastoma, hamartoblastoma, ${ }^{1}$ dysplastic gangliocytoma, ${ }^{2}$ Purkinjeoma, ${ }^{3}$ Lhermitte-Duclos, ${ }^{4}$ gangliocytoma myelinicum diffusum, ${ }^{5}$ benign hypertrophy of the cerebellum, ${ }^{6}$ and finally diffuse ganglioneuroma of the cerebellar cortex. ${ }^{7}$ Each reflects the possible cell of origin, but since that issue is as yet unresolved most refer to it as Lhermitte-Duclos disease (LDD). The first case report by Lhermitte and Duclos in 1920 used the descriptive term "diffuse ganglioneuroma of the cerebellar cortex". ${ }^{8}$ Subsequent papers have added case reports and small series. These have dealt predominantly with clinical and pathologic aspects including immunohistochemistry, ultrastructure and proliferative aspects. By contrast, there are very few papers addressing issues of treatment, the specifics of surgical therapy and their impact on the natural history of the disease.

From the Divisions of Neurosurgery and Neuropathology, The Toronto Hospital, University of Toronto, Toronto.

RECEIVED JULY 3, 1996. ACCEPTED IN FINAL FORM SEPTEMBER 23, 1996.

Reprint requests to: Mark Bernstein, Division of Neurosurgery, Suite 2-405, Mclaughlin Pavilion, 399 Bathurst Street, Toronto, Ontario M5T 2S8 


\section{Case Report}

\section{Clinical History}

A 54-year-old married female of Romanian descent presented with impairment of gait. The previously healthy patient described imbalance precipitating a number of falls over an 18 month duration. She also attested to episodic pain in the occipital and cervical region.

\section{Physical Examination}

Bilateral appendicular dysmetria in addition to truncal ataxia was exhibited. Unsteadiness of gait was also noted. The patient was otherwise neurologically intact.

\section{Imaging}

Plain computed tomographic (CT) scan revealed a homogeneous nonenhancing region of low attenuation in the left cerebellum extending to the vermis. Obstructive hydrocephalus was presumably a result of fourth ventricular compression by the lesion.

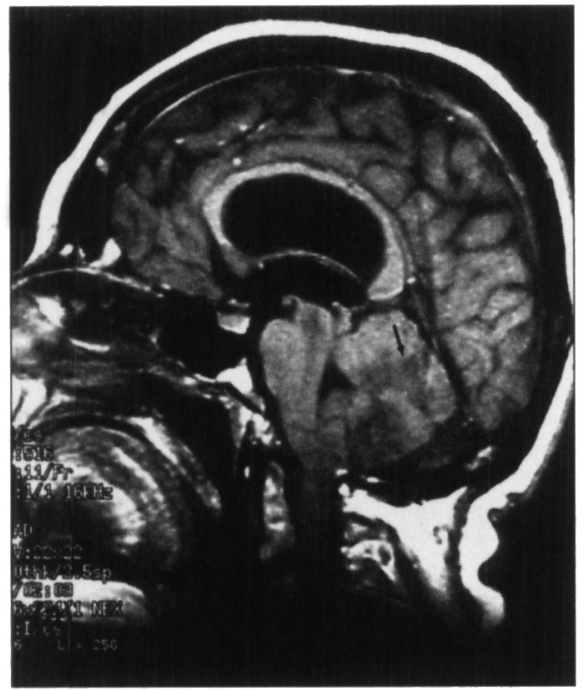

Figure 1: (a) T1 weighted image reveals a low intensity lesion consisting of prominent septations (arrow) and producing mass effect. Secondary compression of the fourth ventricle and hydrocephalus prevails.

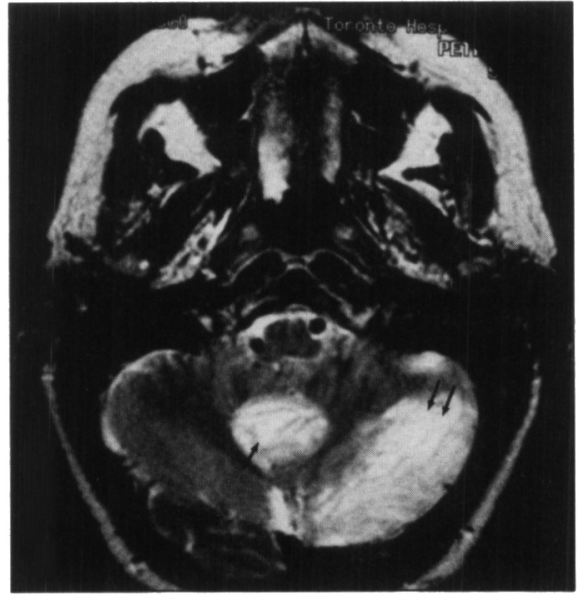

Figure 1: (b) Increased signal intensity on a T2 weighted image reveals $a$ well circumscribed vermian lesion on the right side (arrow) along with a separate lesion involving the left cerebellar cortex (arrows).
Magnetic resonance imaging, (T1 and T2 weighted images) revealed a two part lesion; a well circumscribed vermian lesion on the right side along with a separate lesion involving the left cerebellar cortex. Each consisted of prominent septations and produced mass effect, with secondary compression of the fourth ventricle and hydrocephalus (Figure $1 \mathrm{a}$ and $\mathrm{b}$ ). The areas were of low signal density on T1 weighted (TR $516, \mathrm{TE} 11 / \mathrm{Fr}$ ) images and increased signal density on $\mathrm{T} 2$ weighted imaging (TR 4000,TE 90/Ef) and on proton density (TR 750, TE 12/Fr). No enhancement was noted following intravenous administration of gadolinium.

\section{Operative course}

A left occipital craniectomy followed by resection of the posterior arch of $\mathrm{C} 1$ was performed. A " $Y$ " shaped dural opening revealed enlarged midline vermian tissue of white discoloration along with a separate lesion in the left cerebellar hemisphere. The latter was composed of a poorly demarcated area consisting of obliquely aligned enlarged white gyri. Intraoperative biopsies were obtained using tissue forceps, for pathological evaluation. The site of dural opening was closed using an autologous fascia lata graft. The bone flap was not replaced. This allowed for adequate bony and dural decompression.

\section{Post-operative course}

The patient clinically improved with some amelioration in appendicular and truncal ataxia. Minimal unsteadiness of gait persisted. Followup MRI 11 months post-operatively revealed improvement in hydrocephalus.

\section{Pathology}

Pathologic examination showed multiple small fragments of predominantly abnormal cerebellar cortex. In most of the specimen the normal cortical architecture was altered, the chief abnormality being loss of the normal granule cell layer. This was replaced by a broader zone of altered dysplastic cells with a neuronal immuno-phenoytype, all of which were larger than the normal granule cells (Figure $2 a$ and $b$ ). The dysplastic cells were generally round, of variable size, with a rare cluster of larger ganglionic type cells (Figure $2 \mathrm{c}$ ). In these areas there was loss of the normal Purkinje cell layer. The overlying molecular zone was abnormal containing a prominent plexus of myelinated axons (Figure 2d). Small areas of the specimen showed transition to a normal cerebellar architecture.

The immunohistochemical profile showed strong positivity of the dysplastic cells with antisera to neuron specific enolase (Figure 2e). There were multiple areas of patchy positivity, particularly in the surrounding extracellular neuropil, with antisera to synaptophysin. Neurofilament was largely unreactive with an antibody to the 70 and $200 \mathrm{kd}$ subunits (DAKO 2F-11 monoclonal); only the occasional larger dysplastic cell showed some cytoplasmic positivity. Glial fibrillary acidic protein (GFAP) was unreactive in the dysplastic cells although

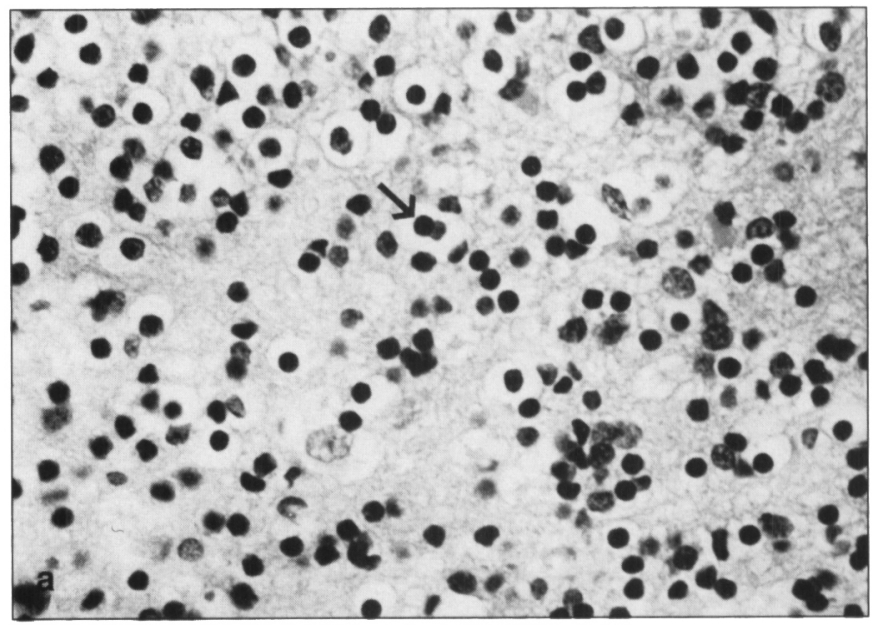

Figure 2a: Histology of predominantly normal granular cell layer of cerebellar cortex adjacent to Lhermitte-Duclos $(L D)$ lesion. Note small, round, normal granule cells (arrow). (Hematoxylin and eosin 100x.) 


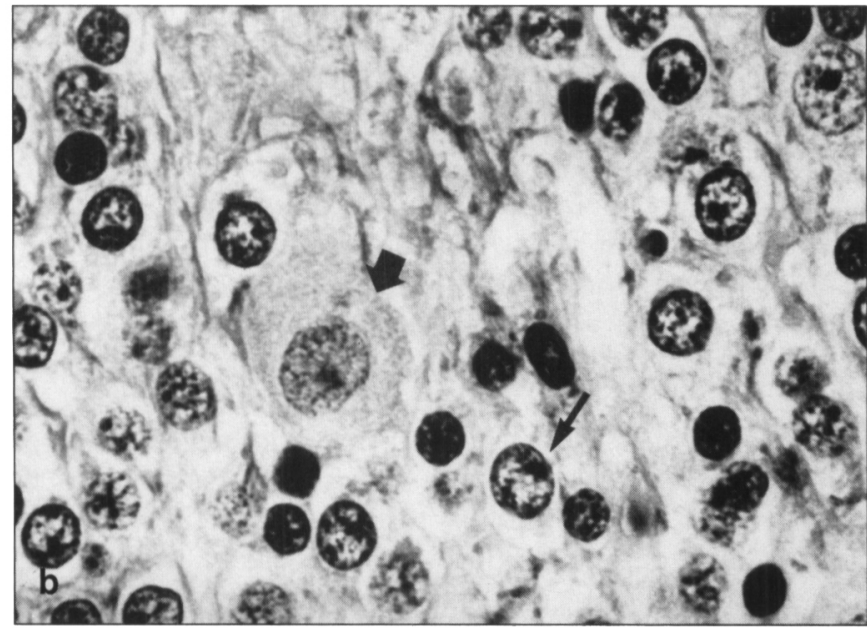

Figure 2b: Dysplastic granule cell layer of LD lesion. Note the slightly larger more pleomorphic cells (thin arrow) with lighter nuclear chromatin. A larger cell with a more neuronal phenotype is present (thick arrow). (Hematoxylin and eosin 250x.)

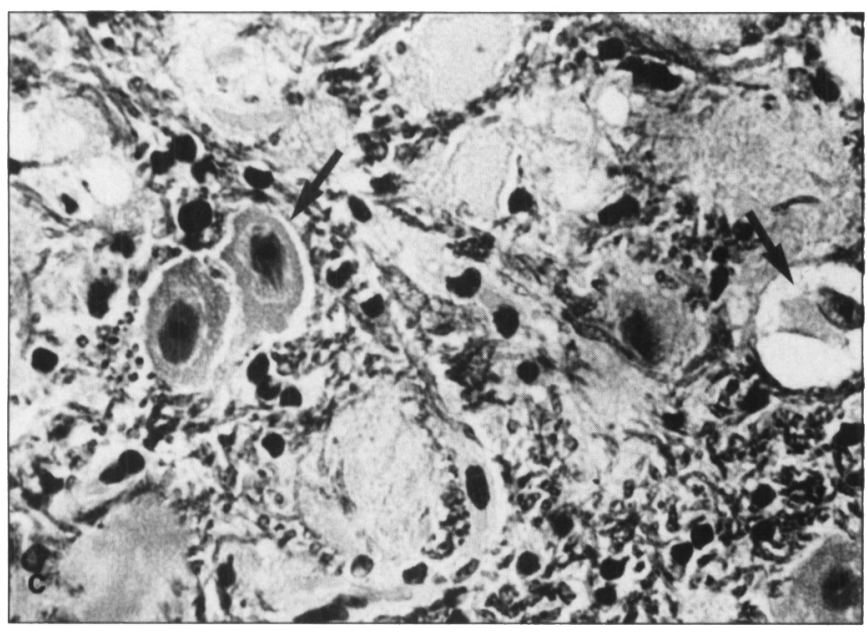

Figure 2c: Cluster of larger ganglionic type cells (arrows) composing a small percentage of the lesion. (Hematoxylin and eosin 250x.)

the superficial aspect of cortex contained a network of radial glial fibres which were GFAP positive. p53 and MIB-1 immuno-histochemistry showed no nuclear immunolabelling of the dysplastic cells.

\section{DisCUSSION}

LDD is clinically manifest as a slowly growing mass in the cerebellar hemispheres. Upon review of the English literature of patients (i.e., non-autopsy cases) with LDD $^{7,9-48,50}$ common features are those of increased intracranial pressure, with $80 \%$ $(40 / 50)$ of patients presenting with headaches, $30 \%$ with nausea and/or vomiting, $42 \%$ with papilledema, and $24 \%$ with diplopia. Signs of cerebellar dysfunction were apparent in a lesser number of patients, with ataxia present in $60 \%$, dysmetria/dysdiadochokinesis in $32 \%$, hypotonia in $8 \%$, and tremors in $10 \%$. Less frequently symptoms of long tract impairment (motor dysfunction, spasticity, hyperreflexia, Babinski reflex) and cranial nerve dysfunction (dysphagia, facial numbness, tinnitus, hearing impairment, vertigo, dysarthria) are present. Unusual cases of orthostatic hypotension and apneic spells, attributed possibly to

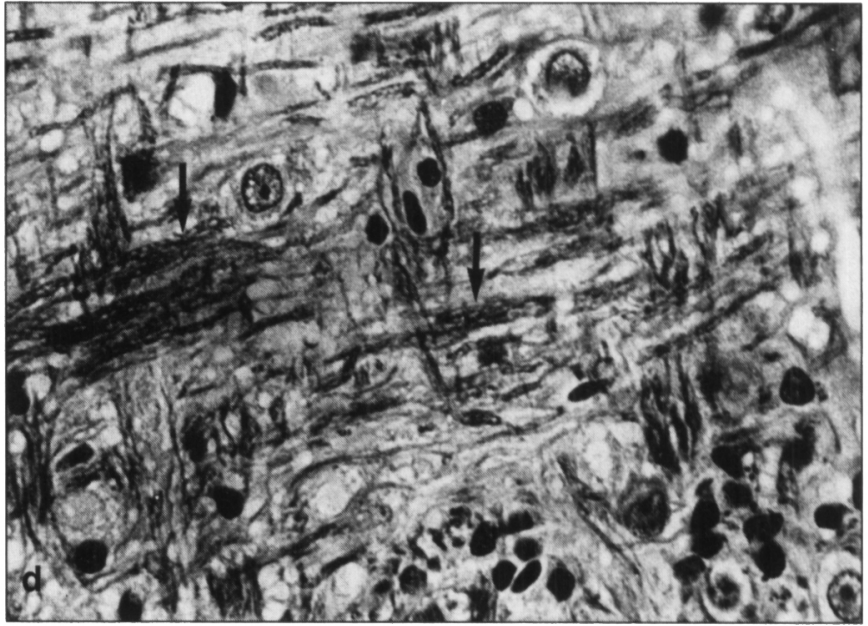

Figure 2d: Plexus of abnormal myelinated axons in the "molecular zone" of the LD cortex (arrows). (Hematoxylin and eosin 150x.)

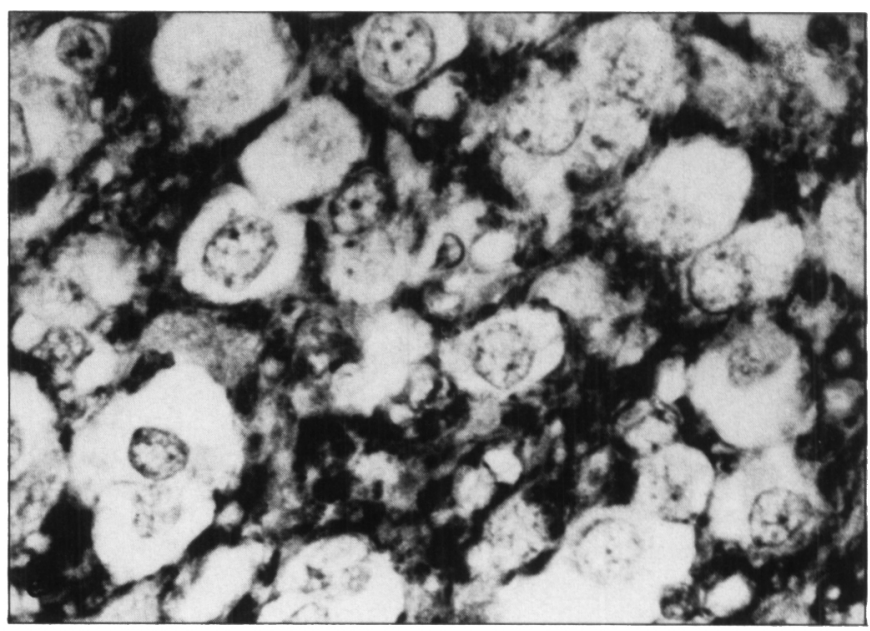

Figure 2e: Immunohistochemistry showing strong cytoplasmic positivity of dysplastic cells for neuron specific enolase, indicating a neuronal like phenotype. (IHC, ABC methods 250x.)

compression of vasomotor centers of the medulla or pons or possibly disturbances of autonomic hypothalamic centers, have also been reported. ${ }^{19,37} \mathrm{~A}$ large number of asymptomatic cases, presenting at autopsy were previously reported by Ambler in a comprehensive histological review of the subject. ${ }^{49}$

The duration of symptoms ranges from a few months to 30 years prior to severe clinical deterioration. Cases mimicking subarachnoid hemorrhage have been reported. ${ }^{39,43}$ One such case presented with $\mathrm{CT}$ evidence of subarachnoid blood outlining the basal cisterns 20 years after a posterior fossa craniectomy and excisional biopsy for LDD. ${ }^{43}$ Angiography proved to be negative, with LDD as the only pathological finding. Age distribution at initial presentation of symptoms varies from 3 days to 63 years. ${ }^{5,79-50}$ Most often patients present in the age range of 3041 years. Three cases of congenital LDD have been described. ${ }^{19,51,52}$ The male to female sex ratio in contrast to the previously reported $1: 1^{45}$ was noted to be $2: 3$ (20:31) not including autopsy cases. ${ }^{5,79-50}$ This is in agreement with Roski et al.'s recognition of a higher female preponderance. ${ }^{36}$ 


\section{Pathology}

The underlying pathogenesis of this disorder remains uncertain, as indicated by the various descriptive names in the literature. The essence of the disorder is a thickened zone of abnormal cells generally thought to be dysplastic granule cells, which largely replace the normal granule cell layer in the affected areas of cerebellar cortex. This leads to abnormal folial architecture which accounts for the enlarged folia seen on MRI. ${ }^{30}$ Within this zone the normal small granule cell neurons are replaced by variably enlarged "dysplastic cells" of a neuronal phenotype. ${ }^{49,53}$ At the margins of the lesion an area of transition from normal granule cells to these dysplastic cells can be seen, indicating that the lesion is not as sharply demarcated as is suggested by MRI. The neuronal phenotype of these cells is confirmed by immunohistochemistry, showing positivity for neuron specific enolase and synaptophysin both in the cells, and in a perisomatic neuropil-like fashion. This is consistent with the known pattern of axosomatic synapses which develop around these cells and confirmed by previous immunohistochemical studies. ${ }^{54}$ It has been suggested that altered regulation of the cytoskletal neurofilament protein plays a role in the abnormal morphology and increased size of the dysplastic cells. ${ }^{48}$ In our case neurofilament immunohistochemistry was largely negative in the dysplastic cells. Although the lesion has been referred to as dysplastic gangliocytoma, the number of larger ganglion type cells is often quite focal, as was seen in this case. Whether the ganglion cells represent Purkinje cells or an extreme form of the hypertrophic dysplastic granule cells is not resolved. Evidence in favour of a Purkinje cell origin is suggested by immunohistochemistry which shows positivity for the pan-T cell antibody anti-leu-4 which stains normal Purkinje cells but not granule cells. ${ }^{53}$ This is of importance because of the different embryologic origins of Purkinje and granule cell neurons. If both cells are involved and abnormal this would support a complex hamartomatous pathogenesis as opposed to a simple dysplasia of granule cells.

The molecular zone of the affected cerebellum is abnormal with loss of Purkinje cells and associated dendrites and synapses. This zone, which is normally axon and myelin free contains prominent projecting axons of the dysplastic granule cells which undergo aberrant myelination. The presence of abnormal myelination further support a hamartomatous process. Other pathologic changes described in LDD were not present in our case, including dysplastic calcification and, more rarely, a prominent plexus of angiomatous like vessels in the overlying meninges. ${ }^{42}$

Although the morphologic features of LDD have been well characterized, the fundamental pathogenesis remains undetermined. There is considerable controversy as to whether this represents a malformative lesion or a neoplastic process. ${ }^{19,20,49,55}$ Although this lesion tends to be very slowly progressive, clinically and radiologically it does slowly enlarge and can even recur following partial surgical resection. The basis of this enlargement and/or recurrence is not clear. It may represent a true increase in the number of cells (dysplastic granule cells) or an increase in size, in conjunction with increasing myelination of the molecular zone axonal plexus. However, the relative contribution of these processes has not been defined. There is no evidence in support of a neoplastic process and much evidence against one. The process does not invade surrounding brain tissue nor does it metastasize. Progression is extremely slow, and there is an absence of significant mitotic activity ${ }^{13,49}$ and cellular proliferation is minimal at most. Kinetic studies have shown little or no proliferative activity as shown by bromo-deoxyuridine labelling, and PCNA (proliferating cell nuclear antigen) or MIB1 immunostaining. ${ }^{23,56}$ This is consistent with our immunostudies showing no MIB-1 immunolabelling of dysplastic cellular elements (MIB-1 is a paraffin analogue of Ki67 generally felt to be a better proliferation marker than PCNA).

The recent association of LDD with Cowden disease is consistent with a malformative process. Cowden disease consists of multiple hamartomas involving ectoderm, mesoderm and endodermal layers. Numerous cases of LDD have now been reported in Cowden syndrome families (up to as many as $30 \%$ ) and indeed, from a clinical point of view, all patients with one disease should be screened for the presence of the other. ${ }^{9,27,32,47,57,58}$ Although a number of cancers occur with increased incidence in Cowden syndrome, chiefly breast, carcinoma, there is no association with, or increased incidence of CNS neoplasia. The presence of LDD arising congenitally in three cases, also supports and is consistent with a malformative nature of the process. ${ }^{19,51,52}$

\section{Treatment}

Currently, a marked paucity of information regarding treatment strategies exists. Only sporadic case reports with extensive information regarding histology and pathology exist on the subject, yet little recourse for management prevails. Reasoning for resection, degree of resection, or outcomes of therapy, are lacking in the majority of the reports. Current modes of treatment described in the literature have consisted of medical (medications or radiotherapy) or surgical, consisting of VP shunt or biopsy and lesion debulking. No reports of long term medical treatment are described. Only one case of resolution of symptoms within 48 hours with mannitol and acetazolimide is described in the literature. ${ }^{42}$ The efficacy of radiotherapy in LDD with essentially no proliferative activity, is unknown. Five cases of such a treatment have been described..$^{9,12,25,29,35}$ One of five actually worsened over a 7 year duration subsequent to the initial intervention, requiring a subtotal resection.

The first case report of surgical intervention was in 1930 by Bielschowski and Simons and described a 20 -year-old who presented with unsteadiness of gait, headaches and paresthesias in all limbs, vertigo, bilateral papilledema and coarse nystagmus. ${ }^{1}$ Of the first 12 reported cases of LDD from 1920 to 1955, 10 died. 5/10 cases were deaths on the operating table or immediately post-operatively, and the rest died prior to any surgical resection. ${ }^{1-3,8,31,59-64}$ In reviewing the English literature on LDD (diagnosed prior to autopsy), reports of surgical intervention have been described in 46/51 cases. ${ }^{7,9-50}$ of the remaining 5 cases, two were reviews of prior reports. ${ }^{29,47}$ No information regarding degree of decompression was provided in one case acknowledged in Ambler's composite review on the subject. ${ }^{49}$ Lastly, two cases were treated without resective therapy. ${ }^{25,42}$ One case received mannitol and acetazolemide as the primary mode of therapy, ${ }^{42}$ while the other was treated with a ventriculocervical shunt and radiation alone on the incorrect presumptive diagnosis of an astrocytoma. ${ }^{25}$ CSF drainage (temporary or permanent) has been reported in 20 of the 46 patients who received a biopsy, subtotal resection or a total resection. With 
of subtotal resection, and $8 / 46$ of complete resection have been described. Inadequate information, as to the degree of resection, is present for the remaining cases (i.e., 8/46). Little information as to the reasoning for the different options is provided. With evidence of a malformative lesion, LDD requires less invasive treatment. Resection of malformed tissue with minimal or no proliferative activity may not be the most optimal decision. The majority of symptoms, due to intracranial hypertension (i.e., headaches, nausea, vomiting, papilledema and diplopia) and local compression (cranial nerve and long tract findings) require treatment. Resection of abnormal cerebellar tissue does not relieve cerebellar symptoms but does decompress the posterior fossa and reduces intracranial hypertension. Ventriculoperitoneal shunting relieves the obstructive hydrocephalus, but allows for the local compressive effects of the lesion to persist. To incorporate treatment of the latter (space occupying lesion) in addition to the former (increased ICP) a method needs to be devised such that decompression of the malformed lesion is carried out. Subtotal or complete resection, well defined in the literature certainly would resolve both issues. The major flaw that exists is the poorly defined boundaries for resection, leading to resection of normal tissue.

Our case demonstrated a unique method in treatment of the malformation, allowing for resolution of both issues. The method involved decompression of the posterior fossa allowing for resolution of compressive symptoms upon the brain stem, adjacent cerebellum and fourth ventricle (thus also obstructive hydrocephalus). A craniectomy, in addition to a $\mathrm{C} 1$ laminectomy followed by a decompressive duroplasty (using autologous fascia lata graft) was performed. Decompression of the bony component in addition to the dura was achieved. The only other report of such a procedure was performed by Oppenheimer upon a 52year-old presenting with a multitude of symptoms over an 18 month period. ${ }^{31}$ A posterior fossa decompression via a craniectomy and non-closure of the dura along with placement of a temporary ventriculostomy, was initially performed. A subsequent operative procedure was carried out a few weeks later due to frequent headaches despite improvement in the rest of the symptoms. Amputation of the obstructive tonsil and dural coverage with a fascial patch was carried out with success. Resolution of all other symptoms long after removal of the ventriculostomy, and prior to the second operation, proves the usefulness of dural decompressive surgery in Oppenheimer's case. The above is certainly substantiated by our case as in many other malformatative lesions of the posterior fossa (e.g., Chiari malformation). ${ }^{65}$

\section{REFERENCES}

1. Bielschowsky M, Simons A. Uber diffuse hamartome (ganglioneurome) des Kleinhirns und ihre Genese. J F Psychol Neurol 1963; 40: 395.

2. Foerster O, Gagel O. Ein Fall von Gangliocytoma Dysplasticum des Kleinhirns. Ztschr Nervenh 1959; 146: 792.

3. Christensen E. Uber Ganglienzellgeschwulste im Gehirn. Virchows Arch Path Anat 1937; 300: 567

4. Bignami JC, De Matteis A. La Malattia di Lhermitte e Duclos del Cervelletto (Ganglioneuroma dysplastico). Riv Anat Pat 1956; 11: 523 .

5. Courville CB. Gangliocytoma myelinicum diffusum of the cerebellar cortex. Bull Los Angeles Neurol Society 1958; 23: 72.

6. Fischer W, Busch KT. Gangliozytome. Klinische und Morphologische Betrachtungen Zbl. Neurochir 1963; 23: 286.
7. Dilorenzo N, Lunardi P, Fortuna A. Granulomolecular hypertrophy of the cerebellum (Lermitte-Duclos disease). Case report. J Neurosurg 1984; 60(3): 644-646.

8. Lhermitte J, Duclos P. Sur un Ganglioneurome Diffus du cortex du cervelet. Bull Assoc Franc Cancer 1920; 9: 99.

9. Albrecht S, Haber RM, Goodman JC, Duvic M. Cowden syndrome and Lhermitte-Duclos disease. Cancer 1992; 70(4): 869-876.

10. Ashley DG, Zee C, Chandrasoma PT, Segall HD. LhermitteDuclos disease: CT and MR findings. J Comput Assist Tomogr 1990; 14(6): 984-987.

11. Banerjee AK, Gleadhill CA. Lhermitte-Duclos disease (diffuse cerebellar hypertophy); prolonged post-operative survival. Irish $\mathbf{J}$ Med Sci 1979; 148(3): 97-99.

12. Bellamy JC, D’Amato NA, Szakacs JE. Diffuse cerebellar hypertrophy. Report of a case. Am J Clin Pathol 1963; 395-404.

13. Beuche W, Wickboldt $\mathbf{J}$, Friede RL, Lermitte-Duclos disease - its minimal lesion in electron microscope data and CT findings. Clini Neuropathol 1983; 2(4): 163-170.

14. Brown WR, Angelo JN, Kelly DL. Lhermitte-Duclos disease: case report with computerized tomographic. Neurosurg 1980; 6(2): 189-191.

15. Carter JE, Merren MD, Swann KW. Preoperative diagnosis of Lhermitte-Duclos disease by magnetic resonance imaging: case report. J Neurosurg 1989; 70(1): 135-137.

16. Choudhaury AR. Pre-operative magnetic resonance imaging in Lhermitte-Duclos disease. Br J Neurosurg 1990; 4: 225-230.

17. Christian HJ. So-called "gangliocytoma" of the cerebellum. J Neurosurg 1961; 18: 125-128.

18. Cook T, Holt S, Yates PO. Diffuse hypertrophy of the cerebellum. J Neurol Neurosurg and Psychiatry 1962; 25: 218-221.

19. Dietlein M, Schroder R, Widemann B, Benz-Bohm G. Dysplastic gangliocytoma of cerebellum in a newborn. Diagnosis by ultrasonography and MRI. Pediatr Radiol 1992; 22(2): 131-133.

20. Faillot T, Sichez JP, Brault JL, et al. Lhermitte-Duclos disease (dysplastic gangliocytoma of the cerebellum). Report of a case and review of the literature. Acta Neurochir 1990; 105: 44-49.

21. Ferrer I, Isamat F, Lopez-Obarrio L, et al. Parvalbumin and calbindin D-28K immunoreactivity in central ganglioglioma and dysplastic gangliocytoma of the cerebellum. Report of two cases. J Neurosurg 1993; 78(1): 133-137.

22. Frerbeau P, Marty-Double C, Castan-Tarbouriech E, Privat JM, Benezech J. Cerebellar gangliocytoma dysplasticum in an infant. Neurochirurgia 1978; 21(6): 212-220.

23. Hair LS, Symmans F, Powers JM, Carmel P. Immunohistochemistry and proliferative activity in Lhermitte-Duclos disease. Acta Neuropathol 1992; 84(5): 570-573.

24. Hashimoto M, Fujimoto K, Shinoda S, Masuzawa T. Magnetic resonance imaging of ganglion cell tumors. Neuroradiology 1993; 35(3): 181-184.

25. Heitkamp JW, Rose JE. Neck pain following migration of a ventriculocervical shunt. Surg Neurol 1983; 19: 285-287.

26. Hulcelle P, Dooms G, Vermonden J. Lhermitte-Duclos disease. A case report. J Neuroradiol 1994; 21(1): 40-45.

27. King MA, Terence JC, Spearritt DJ, Boyle RS. Lhermitte-Duclos disease and Cowden disease: a third case. Ann Neurol 1992; 32(1): 112-113.

28. Leech RW, Christoferson LA, Gilbertson RL. Dysplastic gangliocytoma (Lhermitte-Duclos disease of the cerebellum). Case report. J Neurosurg 1977; 47(4): 609-612

29. Marano SR, Johnson PC, Spetzler RF. Recurrent Lhermitte-Duclos disease in a child. Case report. J Neurosurg 1988; 69(4): 599603.

30. Milbouw G, Born JD, Martin D, et al. Clinical and radiological aspects of dysplastic gangliocytoma (Lhermitte-Duclos disease) a report of two cases with review of the literature. (Review) Neurosurgery $1988 ; 22: 124-128$.

31. Oppenheimer DR. A benign "tumour" of the cerebellum. Report on two cases of diffuse hypertrophy of the cerbellar cortex with a review of nine previously reported cases. J Neurol Neurosurg Psychiatry $1955 ; 18: 199-213$.

32. Padberg GW, Schot JD, Vielvoye GJ, Bots GT, de Beer FC. Lhermitte-Duclos disease and Cowden disease: a single phakomatosis. Ann Neurol 1991; 29(5): 517-523. 
33. Radhakrishnan VV, Sandhyamani S, Sharma R, Rout D, Dysplasic gangliocytoma of the cerebellum (LDD) - a case report with review of the literature. Indian J Cancer 1992; 29(2): 86-89.

34. Reeder RF, Saunders RL, Roberts DW, Fratkin JD, Cromwell LD. Magnetic resonance imaging in the diagnosis and treatment of Lhermitte-Duclos disease (dysplastic gangliocytoma of the cerebellum). Neurosurgery 1988; 23(2): 240-245.

35. Reznick M, Schoenen J. Lhermitte-Duclos disease. Acta Neuropathol 1983; 59(2): 88-94.

36. Roski RA, Roessmann U, Spetzler RF, Kaufman B, Nulsen FE. Clinical and pathological study of dysplastic gangliocytoma. Case report. J Neurosurg 1981; 55(2): 318-321.

37. Ruchoux MM, Gray F, Gherardi R, et al. Orthostatic hypotension from a cerebellar gangliocytoma (Lhermitte-Duclos disease). Case report. J Neurosurg 1986; 65(2): 245-248.

38. Sabin HI, Lidov HG, Kendall BE, Symon L. Lhermitte-Duclos disease (dysplastic gangliocytoma): a case report with CT and MRI. Acta Neurochir 1988; 93(3-4): 149-153.

39. Shanley DJ, Vassallo CJ. Atypical presentations of LhermitteDuclos disease: preoperative diagnosis with MRI. Neuroradiology 1992; 34: 103-104.

40. Siddiqi SN, Fehlings MG. Lhermitte-Duclos disease mimicking adult-onset aqueductal stenosis. Case report. J Neurosurg 1994; 80(6): 1095-1098.

41. Smith RR, Grossman RI, Goldberg HI, et al. MR imaging of Lhermitte-Duclos disease: a case report. Am J Neuroradiol 1989; 10(1): 187-189.

42. Sonier CB, Feve JR, Kersaint-Gilly DE, et al. E. Lhermitte-Duclos disease. A rare cause of intracranial hypertension in adult. J Neuroradiol 1992; 19: 133-138.

43. Stapelton SR, Wilkins PR, Bell BA. Recurrent dysplastic cerebellar gangliocytoma (Lhermitte-Duclos disease) presenting with subarachnoid haemorrhage. $\mathrm{Br} J$ Neurosurg 1992; 6(2): 153-156.

44. Vieco PT, Del Carpio-O'Donovan, Melanson D, et al. Dysplastic gangliocytoma (Lhermitte-Duclos disease): CT and MR imaging. Pediatr Radiolo 1992; 22: 366-369.

45. Vinchon M, Blond S, Lejeune JP, et al. Association of LhermitteDuclos and Cowden disease: report of a new case and review of the literature. J Neurol Neurosurg Psychiatry 1994; 57(6): 699-704.

46. Wells GB, Todd ML, David NY, Zager EL. Lhermitte-Duclos disease and Cowden's syndrome in an adolescent patient. Case report. J Neurosurg 1994; 81: 133-136.

47. Williams DW, Elster AD, Ginsberg LE, Stanton C. Recurrent Lhermitte-Duclos disease: report of two cases and association with Cowden's disease. Am J Neuroradiol 1992; 13(1): 287-290.

48. Yachnis AT, Trojanowski JQ, Memmo M, Schlaepfer WW. Expression of neurofilament proteins in the hypertrophic granule cells of Lhermitte-Duclos disease: an explanation for the mass effect and the myelination of parallel fibres in the disease state. J Neuropathol Exp Neurol 1988; 47(3): 206-216.
49. Ambler M, Pogacal S, Sidman R. Lhermitte-Duclos disease (granule cell hypertrophy of the cerebellum). Pathological analysis of the first familial cases. J Neuropathol Exp Neurol 1969; 28(4): 622-647.

50. Harff EG, Vinken PJ. A case of diffuse cerebellar hypertrophy. Acta Neuropathol 1966; 6(106).

51. Richieri-Costa A, Frederigue U, Guion-Almeida ML. Holoprosencephaly, hamartomatous growth of the cerebrum, dysplatic gangliocytoma of the cerebellum, unique brain anomalies, and renal agenesis in a Brazilian infant born to a diabetic mother: a clinical and pathologic study. Birth Defects 1993; 29(1): 389-394.

52. Roessman U, Wongmongkolrit. Dysplastic gangliocytoma of cerebellum in a newborn. Case report. J Neurosurg 1984; 60: 845847.

53. Schiurba RA, Gessaga EC, Eng LF, et al. Lhermitte-Duclos disease. An immunohistochemical study of the cerebellar cortex (Review). Acta Neuropathol 1988; 75(5): 474-480.

54. Prichett PS, King TI. Dysplastic gangliocytoma of the cerebellum: an ultrastructural study. Acta Neuropathol 1978; 42: 1-5.

55. DeLeon GA, Grant JA, Darling CF. Monstrous, crablike hypertrophy of the cerebellar vermis and its relationship with LhermitteDuclos disease. J Neurosurg 1996; 85: 157-162.

56. Meyer JS, Marchosky JA, Hickey WF. Cell kinetic classification of tumors of the nervous system by DNA precursor labeling invitro. Human Pathol 1993; 24(12): 1357-1364.

57. Russell JR, O'Brien M, Wells RS. Cowden's syndrome. Br J Dermatol 1981; 105(19): 57-58

58. Eng C, Murday V, Seal S, et al. Eeles RA. Cowden syndrome and Lhermitte-Duclos disease in a family: a single genetic syndrome with pleiotrophy? J Med Genet 1993; 31(6): 458-461.

59. Aljouanine T, Bertrand I. Dysplasia Laminaire Hypertrophique du cervelet associee a une malformation renale, avec gigantisme tissulaire. Rev Neurol 1952; 8: 289.

60. Barten H. Eine seltene fehlbildung des kleinhirns. Beitr Path Anat 1934; $93: 219$

61. Duncan D, Snodgrass SR. Diffuse hypertrophy of the cerebellar cortex (myelinated neurocytoma). Arch Neurol Psychiatry 1943; 50: 677 .

62. Heinlen H, Falkenberg G. Beirag zur kasuistik der ganglioneurome des Kleinhirns. Ztschr f d ges Neurol u Psychiat 1939; 166: 128.

63. Schmidt MB. Uber halbseiigen riesenwuchs des schadels und seine beiziehung zu leontiasis und ostits fibrosa. Beitr Anat des Ohres 1926; 23: 594.

64. Spiegel E. Hyperplasia des kleinhirns. Beitr path Anat 1920; 67: 539.

65. Penfield W, Coburn DF. Arnold-Chiari malformation and its operative treatment. Arch Neurol Psychiatry 1938; 40: 328. 